研究ノート

\title{
ジャガイモ抽出液のジャガイモ澱粉の 老化促進効果について
}

\author{
鈴 木 綾 子* 檜 作進** \\ (昭和 49 年 7 月 25 日受理)
}

\author{
The Promotion of Retrogradation of Potato Starch Paste \\ by Potato Extract \\ Ayako Suzuki* and Susumu HizUKURI** \\ *Osaka Women's University \\ (3 Tezukayamahigashi, Sumiyoshi-ku, Osaka-shi, Japan) \\ **Faculty of Agriculture, Kagoshima University \\ (1 Koorimoto, Kagoshima-shi, Japan)
}

\begin{abstract}
Potato starch suspensions in water and water extract of potato were heated at $100^{\circ} \mathrm{C}$ for $5 \mathrm{~min}$. The pastes, thus prepared, were kept at about $5^{\circ} \mathrm{C}$ and the progress of retrogradation was estimated by the method of glucoamylase digestion and $\mathrm{X}$-ray diffraction.

As a result, the more pronounced retrogradation and crystallization were observed in the paste prepared with potato extract than in that with water. This fact may suggest that the cytoplasmic fluid contributes to the crystallization of starch to form the granule in vivo.
\end{abstract}

\section{はじめに}

以前に，私達は種々の植物抽出液がアミロデキストリ ンの結晶化に影響を与え, 生成する結晶型をA型のほう に転移させることを報告した1)。またジャガイモの調理， 加工の際の加熱条件とイモ中の澱粉の老化性との関係に ついて報告した2)。この研究中に，ジャガイモ中の測粉 と精製した澱粉では老化性にかなりの相違がみられるこ とに気づいた。そこでこの相違の原因を明らかにする試 みとして，ジャガイモの抽出液が精製したジャガイモ澱 粉の老化に与える影響を検討した。

\section{実 験 方 法}

溉粉は市販のジャガイモ澱粉を蒸溜水で数回水洗し， 室温で乾燥したものを用いた。

* 大阪女子大学 (大阪市住吉区帝塚山東 3 )

** 鹿児島大学農学部（鹿児島市郡元 1-21-24）
ジャガイモの抽出液は，既報1)と同じ方法で調製した。 すなわち, ジャガイモ $200 \mathrm{~g}$ を $200 \mathrm{ml}$ の蒸溜水ととも に家庭用ミキサーで 1 分間均一化して得た汁液を二重の ガーゼを通して搾汁し，組織片を除いた。この搾汁液を $10,000 \times g$ で 10 分間遠心分離し, 上澄液を沸騰水浴中 で 5 分間熱処理して種々の酵素を不活性化した。このと き生成した不溶物を $10,000 \times g$ で 10 分間遠心分離して 上澄液を抽出液とした。

澱粉の老化は, 以下のように処理した。ジャガイモ澱 粉 $500 \mathrm{mg}$ を $10 \mathrm{ml}$ の水またはジャガイモ抽出液に㲘 濁し, 摚拌しつつ沸騰水溶中で 5 分間加熱糊化した。加 熱後, 約 $5^{\circ} \mathrm{C}$ に急冷し密封して, 同じ温度の冷蔵庫中 において老化せしめた。糊化および老化試料は, $100 \mathrm{ml}$ の $99 \%$ エタノールを入れて高速回転中の家庭用ミキサ 一中に投じ, 急速に混合, 脱水した。生成した澱粉の沈 澱をグラスフィルターで濾別し，フィルター上でさらに 多量の $99 \%$ エタノールを注いで十分脱水し, 次いでエ 一テルで洗浄し, 塩化カルシウム乾燥器中で減圧下に急 


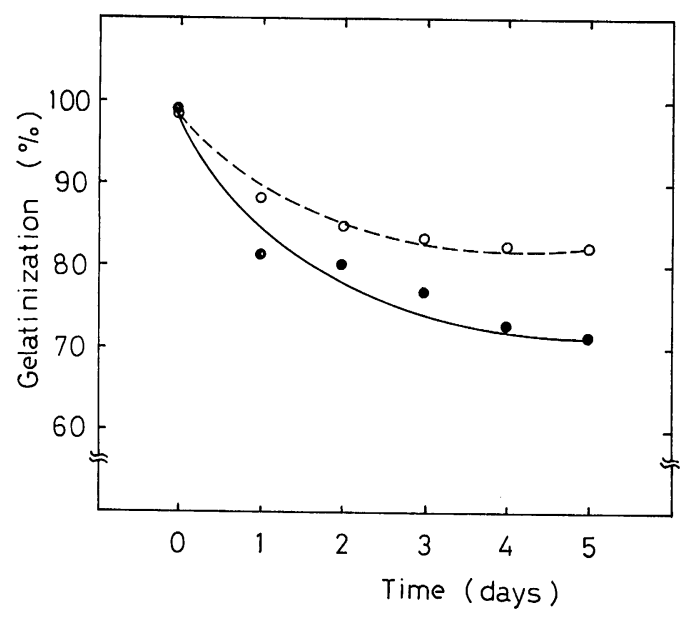

Fig. 1. The retrogradation process of potato starch pastes prepared with water and water extract of potato.

Pastes were kept at $5^{\circ} \mathrm{C}$. The retrogradation was followed by the $\%$ gelatinization estimated by the method of glucoamylase digestion.

$\bigcirc$, water; potato extract.

速に乾燥し, 測定に供した。

糊化度は,グルコアミラーゼ法3)により測定した。

結晶性は, 理学電機製のX線回折装置を用いて評価し た。X線回折装置の操作条件は，既報1)のとおりであ る。

\section{実験結果と考察}

水とジャガイモの抽出液で調製したジャガイモ澱粉糊 の老化の進行は, Fig.1 のようであった。加熱直後の熱 糊液の糊化度は, 両者の場合とも $98 \%$ 程度で完全に糊 化していると判定されたが，糊化度の低下は抽出液を用 いたほうが水の場合より速かであった。5 日間保存後の 糊化度は, 水の場合が $82.5 \%$, 抽出液では $71.5 \%$ であ った。明らかに抽出液では老化が促進されている。外観 的にも, 両者の老化の相違はみられ, 24 時間保存後に抽 出液を用いたほうは離嶈現象が起こったが，水を用いた ほうは不透明になるのみで離漿は起こらなかった。抽出 液は $1.6 \%$ の固形分を含有するが，本実験での澱粉濃度 は 5\% (重量/容量) と薄いため, 抽出液中の固形分によ る水分量の差により, このような相違がもたらされたと は考えられない。

Fig. 2 に水と抽出液の場合の老化測粉のX線回折図を 示した。両者を比較して, 抽出液の場合のほうが明らか

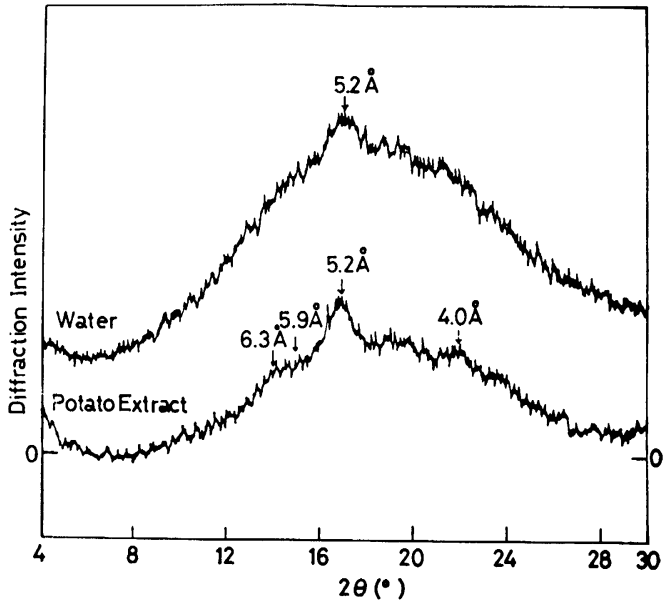

Fig. 2. X-Ray diffractograms of retrograded potato starch pastes prepared with water and water extract of potato.

Pastes were kept at $5^{\circ} \mathrm{C}$ for 5 days.

に結晶化が進んでいることが認められる。老化溉粉の結 晶形は明らかに両者ともに, B 形と判定され, アミロデ キストリンの場合1)にみられたよらに抽出液の場合に $\mathrm{A}$ 形の方向に転移することはみられないが，これは澱粉濃 度が低いことと, 温度が低いことによるものと考えられ る。

これらの事実は, ジャガイモ抽出液がアミロデキスト リンの結晶化を促進すること市 と考え合わせて, この抽 出液中の何らかの成分が測粉の老化と結晶化を促進する ことを示している。今後種々の食品中の澱粉の老化を取 扱う上に留意されるべきことであろう。また，イモの細 胞液が溉粉の結晶化を促進し, 生体内における澱粉粒の 生成に役立っている可能性を示唆するものとして興味深 い。イモの抽出液中のいかなる物質がこのように澱粉の 老化, 結晶化を促進するのか, 各種のイオンの影響も示 唆されている1,4)が，さらに今後の研究にまちたい。

\section{文献}

1）鈴木綾子, 檜作 進, 二国二郎：農化， 43,177 (1969).

2）鈴木綾子, 堀越フサエ, 檜作 進：家政誌，22，16 (1971).

3）外山忠男, 檜作 進, 二国二郎：澱工誌， 13，69 (1966).

4）檜作 進，藤井ミチ子，二国二郎：Biochim. Biophys. Acta, 40, 246 (1960). 